University of Warwick institutional repository

This paper is made available online in accordance with

publisher policies. Please scroll down to view the document

itself. Please refer to the repository record for this item and our

policy information available from the repository home page for further information.

To see the final version of this paper please visit the publisher's website. Access to the published version may require a subscription.

Authors: Lydia Lewi s

Title: Introduction: Mental Health and Human

Rights: Social Policy

and Sociological Perspectives

Year of 2009

publication:

Link to http://dx.doi.org/10.1017/S1474746408004739

published

version:

Publisher None

statement: 



\section{Introduction: Mental Health and Human Rights: Social Policy and Sociological Perspectives}

\section{Lydia Lewis}

Department of Sociology, University of Warwick

E-mail: lydia.lewis@warwick.ac.uk

Recognition of the effects of social, economic, political and cultural conditions on mental health and the personal, social and economic costs of a growing global mental health crisis (WHO, 2001; EC, 2005) mean that mental health and well-being are a current feature of social policy agendas at UK, European and world levels, with debate increasingly becoming framed in human rights terms. In the UK, policy drives to address social exclusion and health inequalities as key social and economic rights issues have encompassed attention to mental health and distress (DoH, 2003; Social Exclusion Unit, 2004) and mental health has been identified as a priority area for the new Equality and Human Rights Commission (Diamond, 2007; DRC, 2007). At the European level too, rights-based social policy approaches to promoting social cohesion (European Committee for Social Cohesion, 2004) and policy directives on the 'right to health' (Commission of the European Communities, 2007) have been centrally concerned with mental health and well-being, and have been accompanied by a European strategy on mental health for the EU (EC, 2005). At a global level, the World Health Organisation has declared enjoyment of the highest attainable standard of health to be a fundamental human right (WHO, 2006). It has launched a new appeal on mental health which draws attention to the impact of human rights violations and cites social isolation, poor quality of life, stigma and discrimination as central issues for those with mental health needs (Dhanda and Narayan, 2007; Horton, 2007; WHO, 2007).

At the same time, in both UK and international arenas, concerns over mental health service provision have increasingly been framed in human rights terms $(\mathrm{DoH}, 2007 \mathrm{a}$; Parker, 2007). In the context of EU enlargement (EC, 2005) and apparently growing mental health needs globally, there have been calls for states to recognise citizens' right to mental health services and heightened debate about how access to and treatment within these can respect or contravene basic human rights. Discussion has centred not only on inadequate or damaging service responses, unequal access to services and the need to more actively involve users (DoH, 2005; Dhanda and Narayan, 2007; Horton, 2007; Parker, 2007; United Nations, 2007; WHO, 2007), but also on increasingly apparent inconsistencies between social policy approaches to mental health and distress and still dominant medical service paradigms (Beresford, 2005). Furthermore, in many Western countries there have been mental health policy imperatives towards increasing coercion and control within a climate of fear and risk to public safety posed by users of services, with controversial new mental health legislation extending the compulsory powers of services outside of hospital-based care being introduced by many states, including in the UK context (see SEHDMHD, 2003; Campbell et al., 2006; DoH, 2007b). Evidently such developments sit uneasily alongside social policy drives to address human rights through tackling stigma and promoting social inclusion for those using mental health services. 
They also call into question how a 'human rights based' culture (DoH, 2007) can be embedded in practice within this service context.

Despite this policy attention, however, and given its centrality to all of our lives, mental health arguably remains marginal within academic and public social policy agendas. Historically, it has been the 'cinderella sector' of the health service, and this low status has been reflected in the academic field. This themed section of a mainstream social policy journal exploring human rights issues and their implications for the development of mental health policy and services may therefore highlight a significant area of debate and help to mainstream discussion of both human rights and mental health within social policy. The papers were all originally presented at a day conference on the theme of 'mental health and human rights: sociological perspectives' hosted by the Sociology of Mental Health Study Group of the British Sociological Association Medical Sociology Group at the University of Warwick in June 2007 (see: www.britsoc.co.uk/medical/MedSocMentalHealth.htm). The papers were selected for the themed section because they address key policy areas for mental health, including 'user involvement', 'social inclusion' and 'recovery', and because they extend the frontiers of debate within these.

A central theme of the collection is how contesting human rights paradigms inform mental health policy and practice and how these need to be reworked for progressive developments to take place. The papers consider the tension underpinning mental health policy of paternalistic or controlling compared to liberating human rights approaches, and how a better balance in favour of emancipatory and empowering service responses and policies could be achieved. This theme is taken up by Helen Spandler and Tim Calton in their discussion of service responses for those experiencing 'psychosis' and by Jo Warner in considering the application to mental health care settings of the ban on smoking in public places in the UK, an issue which has been framed in terms of the right to take risks versus the right to health. The theme is also a feature of the review article by Mick Carpenter, which additionally addresses the effects on mental health services of new 'responsibilisation' strategies under New Labour. These strategies position human rights as conditional, a policy trend also reflected upon in Spandler and Calton's careful analysis and by myself in the context of approaches to 'user involvement' in services.

A second core theme is how understandings of mental health and distress form the foundation for recognising human rights. The papers reflect on the implications of how conceptions of 'mental illness' and 'madness' have traditionally been used to legitimate denial of human rights on the grounds of 'capacity'. Spandler and Calton and Carpenter, in his discussion of mental health legislation, discuss these issues in the context of coercive service interventions. The papers also consider how illness conceptions in the mental health field can undermine the upholding of human rights principles, such as equality and respect through 'misrecognising' people's experiences and denying people full humanity. In this vein, Cresswell elaborates a discussion of 'experiential rights' the right to have one's experiences of distress or trauma recognised and valued in the context of social welfare responses. This core theme is revisted by myself in the context of practices of 'user involvement' in mental health services, which I argue fail to uphold such experiential rights, and by Spandler and Calton in their argument for nonmedical alternatives to treatments for 'psychosis'. These discussions also consider the relationship between different categories of rights, with Cresswell and myself arguing that 
full realisation of social and political rights in practice, and of human rights principles, depends upon social recognition of experience, or the actualisation of experiential rights.

A third feature of our discussions is the relationship between social inequalities and human rights. The articles explore how social inequalities of gender, class, and 'race'/ethnicity, among others, can powerfully frame the specific forms of discrimination and exclusion that often characterise experiences of mental health services and access to rights in this context. Jo Warner's article is compelling here, arguing that anti-smoking campaigns which mobilise stigma are likely to be unhelpful to mental health service users, many of whom occupy lower socio-economic groups. The ways in which gender and class impact on the actualisation of the 'right to participation' in mental health services is a feature of my own article, whilst Mick Carpenter discusses the impact, within the wider human rights agenda, of equalities strategies on the provision of mental health services.

In sum, the collection aims to stimulate debate about the ways in which the renewed focus on human rights at present can be used to take forward core issues in mental health policy and service provision, and to this end some further key sources on this overarching theme are provided last.

\section{References}

Beresford, P. (2005), 'Social approaches to madness and distress: user knowledges and user experience', in J. Tew (ed.), Social Perspectives in Mental Health: Developing Social Models to Understand and Work with Mental Distress, Philadelphia: Jessica Kingsley Publishers.

Campbell, J., Healy, B. and Brophy, L. (2006), 'Mental health policy, law and risk: finding a balance between state paternalism and citizenship rights for people with mental health problems', in L. Sapouna and P. Herrmann (eds.), Knowledge in Mental Health: Reclaiming the Social, New York: Nova Science Publishers.

Commission of the European Communities (2007), Together for Health - A Strategic Approach for the EU 2008-2013, Brussels: The Commission.

Diamond, P. (2007), 'UK developments on equality and rights, plenary address at the Commission for Equality and Human Rights conference, Making Rights Real', Birmingham, UK, 15 November.

Dhanda, A. and Narayan, T. (2007), 'Mental health and human rights', The Lancet, 370, 9590, 1197-8.

DoH [Department of Health] (2003), Tackling Health Inequalities: A Programme for Action, London: Department of Health Publications.

DoH (2005), Delivering Race Equality in Mental Health Care, London: Department of Health Publications.

DoH (2007a), Human Rights in Healthcare: A Framework for Local Action, London: DoH.

DoH (2007b), '2007 Mental Health Act - overview', http://www.dh.gov.uk/en/Policyandguidance/ Healthandsocialcaretopics/Mentalhealth/DH_078743

DRC [Disability Rights Commission] (2007), 'The disability agenda: creating an alternative future', http://www.equalityhumanrights.com

European Committee for Social Cohesion (2004), A New Strategy for Social Cohesion, Brussels: Council of Europe.

EC [European Commission] (2005), Improving the Mental Health of the Population: Towards a Strategy on Mental Health for the European Union, Brussels: EC.

Horton, R. (ed.) (2007), Lancet Series on Global Mental Health, The Lancet, 370, 4, 1-12.

Parker, C. (2007), 'Developing mental health policy: a human rights perspective', in M. Knapp, D. McDaid, E. Mossialos and G. Thornicroft (eds.), Mental Health Policy and Practice across Europe, Maidenhead: Open University Press. 
SEHDMHD [Scottish Executive Health Department Mental Health Division] (2003), An Introduction to the Mental Health (Care and Treatment) (Scotland) Act 2003, Edinburgh: Scottish Executive.

Social Exclusion Unit (2004), Mental Health and Social Exclusion: Social Exclusion Unit Report, Wetherby: Office of the Deputy Prime Minister.

United Nations (2007), 'Convention on the rights of persons with disabilities' Office of the United Nations High Commissioner for Human Rights, http://www.ohchr.org/english/law/disabilities-convention.htm (accessed 21 November 2007).

WHO [World Health Organisation] (2001) World Health Report, Mental Health: New Understanding, New Hope, Geneva, Switzerland: World Health Organisation.

WHO (2006), Constitution of the World Health Organisation, Forty-fifth edition, Geneva, Switzerland: WHO Press.

WHO (2007) 'Mental health: WHO urges more investments, services for mental health', http://ww.who. int/mental_health/en/ (accessed 21 November 2007). 